\title{
Effect on Thermal Performance by Different Types of Fixed Sun Shading Devices
}

\author{
Mohd Fadlullah Gimat, Mohd Khairul Azhar Mat Sulaiman
}

\begin{abstract}
An application of sun-shading device is one of the options to elevate the exterior façade appearance while keeping the thermal performance at the best for the indoor. This research aimed to evaluate the effectiveness of selected types of fixed passive sun-shading devices installed at three-story terrace shop houses in Malaysia. Most previous studies on this passive strategy have been conducted via software simulation, in which results were not validated by field measurement. Therefore, this research employed stationary experiment on actual building and meteorological condition using three types of fixed shading devices: egg crates (SDE), vertical (SDV), and horizontal (SDH). SDE showed significant improvement on indoor thermal environment by reducing indoor air temperature $\left(T_{a}\right)$ of about $0.98 \mathrm{~K}$ on the average of a month and $2.11 \mathrm{~K}$ on the highest temperature on the average of a month. SDE also showed significant performance during the hottest sunny day, in which it reduced $1.23 \mathrm{~K}$ for the average of a day. Meanwhile, on the hottest peak time, SDE reduced $5.40 \mathrm{~K}$ compared to the control room. Similarly, for indoor mean radiant temperature $\left(T_{m r t}\right)$, SDE showed notable performance during the high peak temperature on the average of a month $(2.38 \mathrm{~K})$ and during the hottest day $(7.70$ $K)$ compared to control room, $S D V$, and $S D H$. On top of that, $S D H$ also showed similar performance as SDE on the average of a month by a difference of $0.03 \mathrm{~K}$. The experimental results also indicate that SDH showed the best performance at night by releasing heat faster than other types of sun-shading devices. This passive solution is one of the best options to improve indoor thermal performance and potentially contribute to energy savings on the building operation.
\end{abstract}

Keywords: Fixed sun-shading device, Egg crate shading device, Horizontal shading device, Vertical shading device, Indoor thermal performance

\section{INTRODUCTION}

Building an envelope-boundary between an outdoor and indoor thermal environment plays important roles in regulating thermal environment to provide a livable, healthy, and conducive indoor environment [1]. About $20 \%$ to $60 \%$ of energy use in buildings is affected by the design and

Revised Manuscript Received on February 05, 2020.

* Correspondence Author

M. F. Gimat, Department of Architecture and Planning, Development and Maintainence Office, Universiti Tun Hussein Onn Malaysia, 86400 Batu Pahat, Johor, Malaysia (e-mail: fadlulah@uthm.edu.my)

M. K. A. M. Sulaiman*, Department of Architecture and Built Environment, Fakulty of Engineering and Built Environment, Universiti Kebangsaan Malaysia, 46300 Bangi, Selangor, Malaysia (e-mail: m.khairulazhar@ukm.edu.my)

(C) The Authors. Published by Blue Eyes Intelligence Engineering and Sciences Publication (BEIESP). This is an open access article under the CC BY-NC-ND license (http://creativecommons.org/licenses/by-nc-nd/4.0/) construction of the building envelope [2]-[3]. Extensive energy is needed for cooling the indoor space especially in the tropical climate, which is hot and humid throughout the year. Several passive cooling design strategies have been invented to overcome excessive solar heat gain and heat transfer via building envelope [4]-[10]. Nevertheless, a simple attachment of sun-shading devices on the external surface of a building envelope can also significantly improve the thermal environment of indoor and energy usage [11]-[13]. The connection between temperature and buildings determines the thermal performance of buildings so that the occupants feel comfortable to stay in the buildings [14]. Comfortable and conducive thermal environment can be achieved with the application of passive cooling such as fixed sun-shading device on the external surface of buildings.

The choice of the most effective type of passive sun-shading design is crucial in gaining maximum impact on the thermal performance of the building. Sun-shading device systems are the most important components to elevate the building appearance and are practically used as a heat barrier especially in tropical regions [15]. The sun-shading device system provides significant control of indoor thermal performance, visual comfort, and conditions of spaces and affect energy demands whilst enabling occupants to manage their privacy and view to outside [16]-[20]. A variety of aspects should be considered in sun-shading system design, including thermal requirements, transmittance of daylight and indoor visual impact, safety, aesthetic value, maintenance, cost efficiency, reliability, users' demands, and other utilizations [16]-[17], [21]. The main purpose of a sun-shading system is to protect a building from direct solar radiation [15], [22], where it performs two basic role as a regulator: to improve building performance and create a healthy environment [23].

Passive sun-shading systems include shading devices that follow the passive design approach. The basic notion of this approach is that no energy source is involved. This category is divided into two types: fixed and adjustable shading devices [24]-[25]. Three main considerations influence the effectiveness of shading device, which are the climate and meteorological factors, surrounding site environment, and design objective. The integration between shading devices with a cavity space and two-layer façade

potentially produces a better building design performance [26]. A study measured the indoor thermal performance of three different types of passive sun-shading designs on an actual-scale building and a decrease was 


\section{Effect on Thermal Performance by Different Types of Fixed Sun Shading Devices}

observed in indoor ambient temperature between 1 and $5.75{ }^{\circ} \mathrm{C}$ [27]-[29]. The study was conducted in the hot and dry climate of Jordan, where the climate condition is different with that of this study, which is in the tropics. Meteorological parameter is one of the factors that affect the overall performance of the sun-shading system in providing a more conducive indoor thermal comfort performance. Therefore, this study aimed to investigate the effectiveness of three types of fixed sun-shading devices, namely horizontal (SDH), vertical (SDV), and egg crates (SDE) through comparative thermal performance study.

\section{MATERIALS AND METHODS}

Experiment was conducted at shop house buildings. Basically, in Malaysia, a shop house is a building used for commercial activities at the ground level and for living at the upper floor. However, this function has changed, in which the upper floor is no longer used for residence but for office or commercial activities instead. Nevertheless, the ground floor remains a commercial space. A shop house is a terraced longitudinal building, which can exceed up to $30 \mathrm{~m}$ long, having two or three floors. The selected shop houses for this research are surrounded by widely open parking area on the west and south (frontage) and double-story shop houses on the north.
Four identical units of shop houses were used in this study. The three-story unit is located at Lot 105, 106, 107, and 108, Block A, City Campus, Universiti Tun Hussein Onn Malaysia (UTHM) (Fig. 1). Identical rooms from each unit $\left(10 \mathrm{~m}^{2}\right)$ were selected for the study, which are located frontmost of the building, on the second floor. The rooms were exposed to direct solar radiation (facing west) due to the wide opening of front façade and received the highest thermal radiation. The rooms were identical in terms of size, window openings, materials, and building orientation. All rooms were left empty and no activities were allowed during the measurement-taking process.

Three units were installed with each type of sun-shading device on the exterior of the building, and one room was left bare as a control room. Fig. 2 shows the types of shading devices used in this study, i.e., SDE, SDH, and SDV. All shading devices were designed with $150 \mathrm{~mm}$ depth and gaps for each panel, which were similar designs in previous research done by others. The material of the sun-shading device is aluminum-based with silver paint coatings. Window openings are the most affected by direct solar radiation into the buildings [30]. Therefore, all three types of sun-shading devices covered the windows openings located on each room.

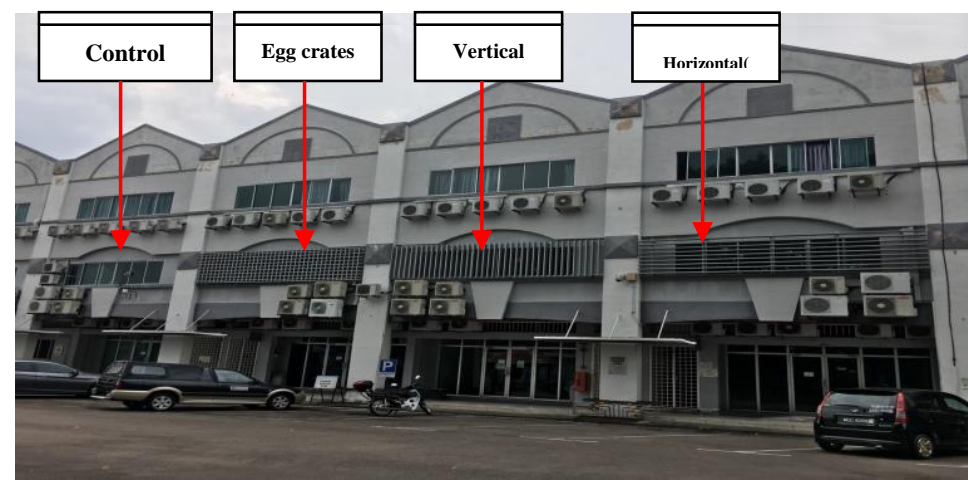

Fig. 1: The three types of shading devices: Egg Crates (SDE), Vertical (SDV), and Horizontal (SDH) installed on the shop house buildings.

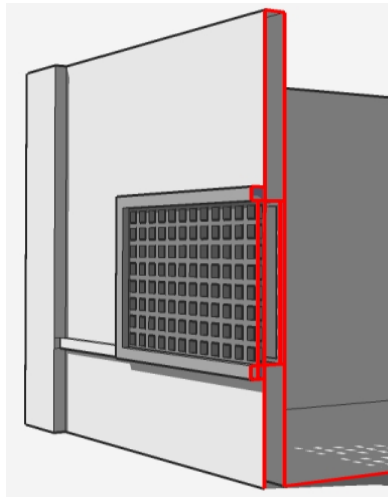

Egg Crates (SDE)

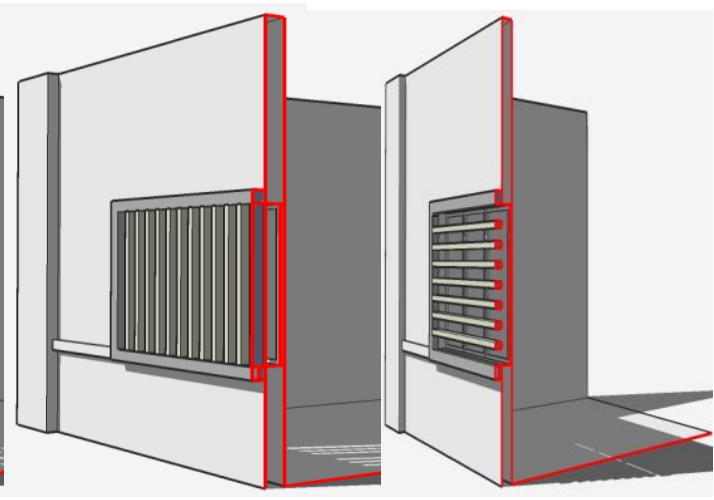

Vertical (SDV)

Horizontal (SDH)

Fig. 2: Details types of fixed sun-shading device used in this study 
The study was conducted for three months (1 May - 31 July 2019) and measurements were taken at 10-min intervals for $24 \mathrm{~h}$. For the present study, only the results for one selected hot and sunny day (7 May 2020) and the average for May 2019 are discussed. Data was collected through field measurement. Each room (Fig. 3) was equipped with thermal comfort meter (Delta Ohm HD32.3 PMV data logger) for indoor data collection. This thermal comfort instrument measured internal air temperature $\left(\mathrm{T}_{\mathrm{a}}\right)$, relative humidity $\left(\mathrm{RH}_{\mathrm{i}}\right)$, globe temperature $\left(\mathrm{T}_{\mathrm{g}}\right)$, and air velocity $\left(\mathrm{V}_{\mathrm{a}}\right)$. Mean radiant temperature $\left(\mathrm{T}_{\mathrm{mrt}}\right)$ was automatically calculated by the instrument.
Outdoor ambient temperature $\left(\mathrm{T}_{\mathrm{ao}}\right)$, relative humidity $\left(\mathrm{RH}_{\mathrm{o}}\right)$, and solar radiation were also measured for outdoor environment. The Onset Hobo U30-NRC weather station was set up to collect background meteorological parameters including wind speed, wind direction, solar radiation, rain, and ambient temperature. All the indoor instruments were installed at a $1 \mathrm{~m}$ height from the floor level and located at the center of each room. All instruments were calibrated in the same room and under control environment before data collection process.

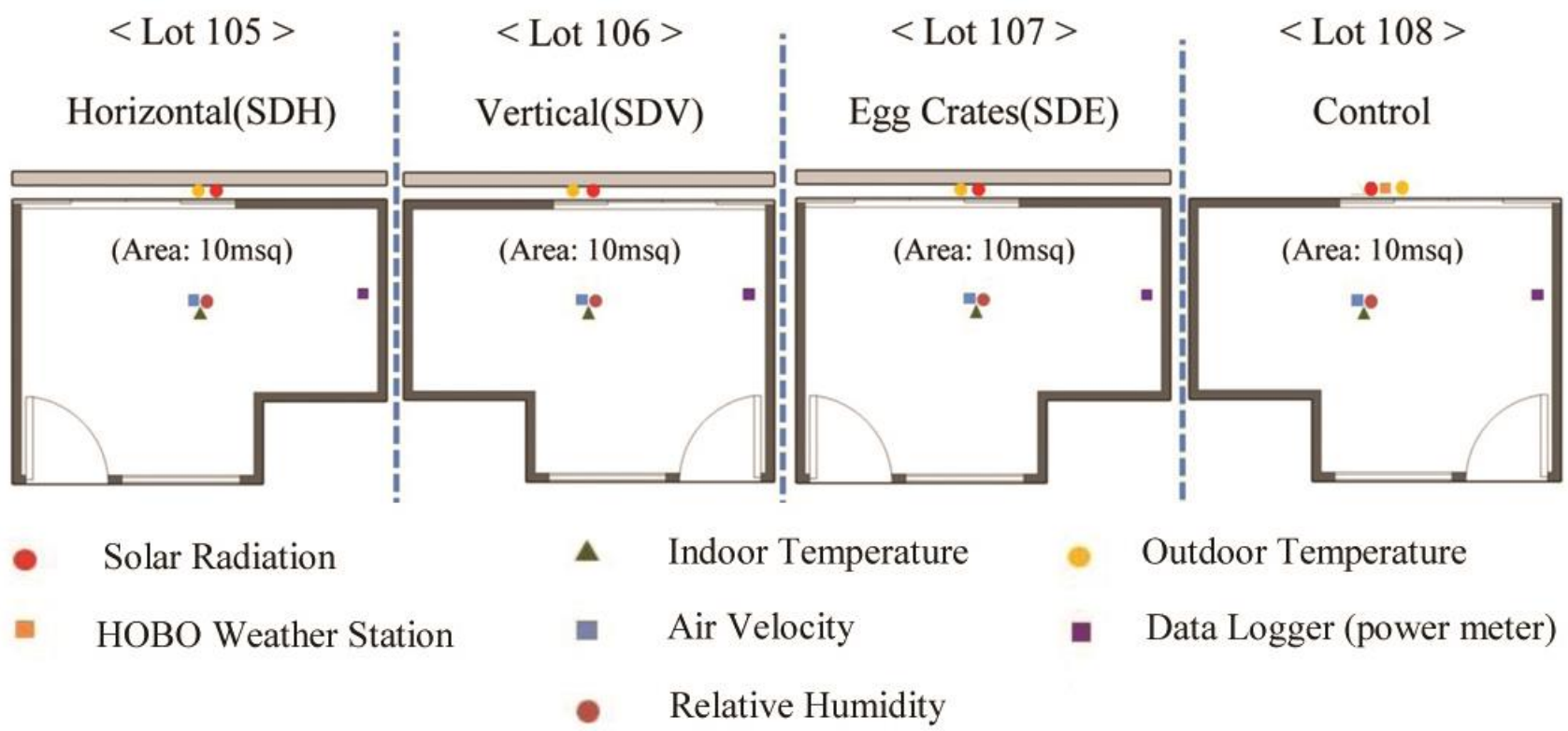

Fig. 3: Floor plan showing the position ofoinstruments set un at the research area.

\section{RESULTS AND DISCUSSION}

The results shown are indoor air temperature $\left(\mathrm{T}_{\mathrm{a}}\right)$ and mean radiant temperature $\left(\mathrm{T}_{\mathrm{mrt}}\right)$, which show the thermal performance of the interior. Results for the selected day of experiment (hot and sunny day, 7 May 2019) and the average of one month (May 2019) are shown.

\section{A. Indoor Air Temperature $\left(\mathrm{T}_{a}\right)$}

Indoor air temperature is the most important indicator in investigating cooling effect performance. The higher reduction of indoor air temperature indicates a better cooling effect performance of the sun-shading device. Fig. 4 and Table I shows the results of the comparisons of internal air temperatures $\left(\mathrm{T}_{\mathrm{a}}\right)$ generated from each room fitted with $\mathrm{SDH}$, SDV, and SDE, as well as control room that did not have any sun-shading device installed. Throughout the $24 \mathrm{~h}$ measurement, the highest $\mathrm{T}_{\mathrm{a}}$ was $39.20{ }^{\circ} \mathrm{C}$ recorded at 1810 (7 May 2019) in the control room.

For the rooms installed with fixed sun-shading devices, SDE room performed the best in reducing indoor air temperature by a reduction of $5.40 \mathrm{~K}$. This was followed by SDV room with a reduction of $5.10 \mathrm{~K}$, and SDH room with a reduction of $4.20 \mathrm{~K}$. Throughout the $24 \mathrm{~h}$ experiment duration, the average SDE room $\mathrm{T}_{\mathrm{a}}$ was reduced to $1.23 \mathrm{~K}$, followed by SDV $(1.10 \mathrm{~K})$ and $\operatorname{SDH}(0.91 \mathrm{~K})$. The average $\mathrm{T}_{\mathrm{a}}$ recorded in the control room was $33.55^{\circ} \mathrm{C}$.

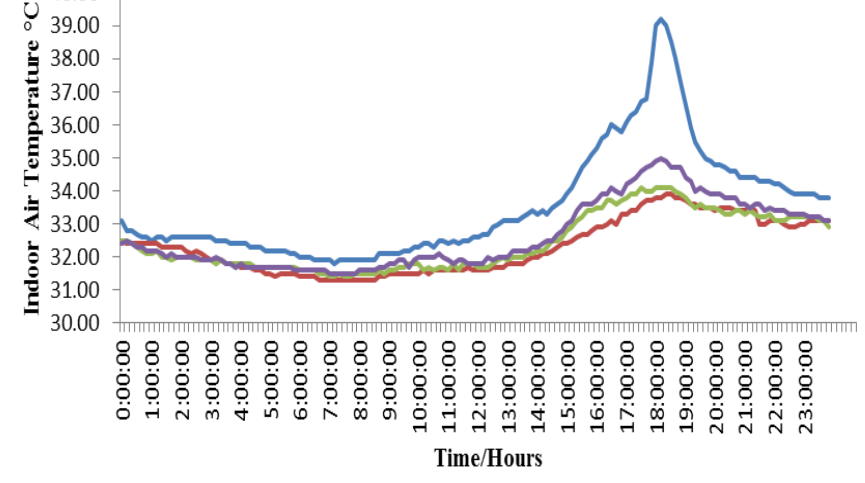

Fig. 4: Comparison of air temperature $\left(\bar{T}_{\mathbf{a}}\right)$ genenerated by each room on the sun-shading performance recorded on 7 May 2019.

Table I: Comparison of sun-shading devices performances compare to the highest $\left(T_{a}\right)$ at control room recorded on 7 May 2019.

\begin{tabular}{|l|c|c|}
\hline $\begin{array}{c}\text { Type of Sun-Shading } \\
\text { Device }\end{array}$ & $\begin{array}{c}\text { Indoor Air } \\
\text { Temperature } \mathbf{~ ( ~}_{\mathbf{a}} \text { ) }\end{array}$ & $\begin{array}{c}\text { Temperature } \\
\text { Difference }\end{array}$ \\
\hline Egg crates (SDE) & $33.80^{\circ} \mathrm{C}$ & $5.40 \mathrm{~K}$ \\
\hline Vertical (SDV) & $34.10^{\circ} \mathrm{C}$ & $5.10 \mathrm{~K}$ \\
\hline Horizontal (SDH) & $35.00^{\circ} \mathrm{C}$ & $4.20 \mathrm{~K}$ \\
\hline
\end{tabular}


On the average hours of one-month measurement (Fig. 5 and Table II), the highest ambient temperature ( $\mathrm{T}_{\mathrm{a}}$ ) was 34.44 ${ }^{\circ} \mathrm{C}$, recorded at 1900 in the control room. SDE room performed the best by showing a reduction of $2.75 \mathrm{~K}$. The results also show reduction of temperature in both SDV (2.60 $\mathrm{K})$ and SDH (2.32 K) rooms. SDE performed moderately all the time and the reduction of temperature showed the best result during daytime. These results also support a simulated previous study, which showed that the SDE device resulted in more comfort hours in a year compared to SDV and SDH [15].

A previous study done using simulation [31] on comparing SDE, SDH, and SDV performance showed that egg crates performed the best on reducing power consumption and increasing energy savings up to 9.9\%-10.4\%. Another research on the field study showed that SDE lowered the indoor building temperature up to $10 \%$, compared to SDV which only reduced the temperature by $6 \%$ [29]. This finding shows that shading devices with different designs will produce a significant results in energy consumption. Therefore, this study can be further explored on the impact of each type of sun-shading device toward the energy-saving process.

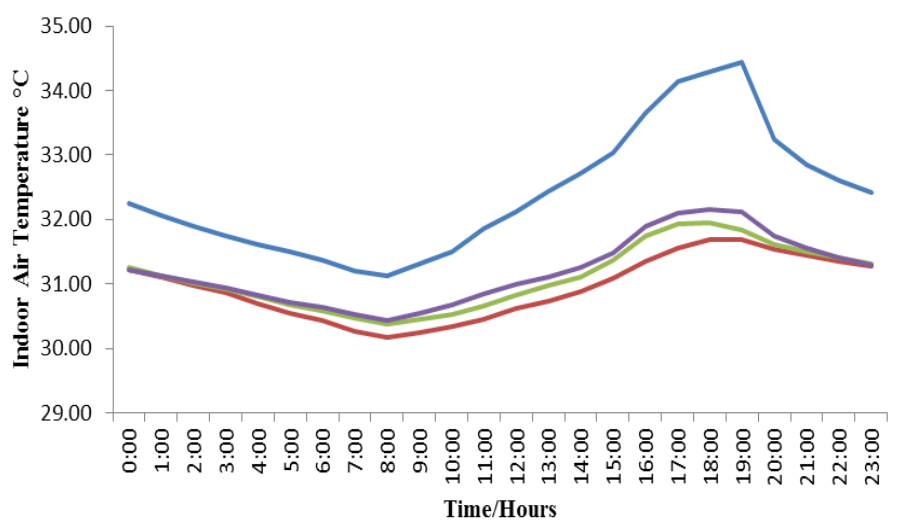

Control -Egg Crates(SDE) - Vertical(SDV) - Horizontal(SDH)

Fig. 5: Comparison of indoor air temperature $\left(T_{a}\right)$ generated by each room on the sun-shading performance recorded in one month (May 2019).

Table II: Comparison of sun-shading devices performances compare to the highest $\left(T_{a}\right)$ at control room recorded in one month (May 2019).

\begin{tabular}{|l|c|c|}
\hline $\begin{array}{c}\text { Type of Sun-Shading } \\
\text { Device }\end{array}$ & $\begin{array}{c}\text { Indoor Air } \\
\left.\text { Temperature } \mathbf{( T}_{\mathbf{a}}\right)\end{array}$ & $\begin{array}{c}\text { Temperature } \\
\text { Difference }\end{array}$ \\
\hline Egg crates (SDE) & $31.69^{\circ} \mathrm{C}$ & $2.75 \mathrm{~K}$ \\
\hline Vertical (SDV) & $31.84^{\circ} \mathrm{C}$ & $2.60 \mathrm{~K}$ \\
\hline Horizontal (SDH) & $32.12^{\circ} \mathrm{C}$ & $2.32 \mathrm{~K}$ \\
\hline
\end{tabular}

\section{B. Indoor Mean Radiant Temperature ( $\left.\mathbf{T}_{\mathrm{mrt}}\right)$}

On the hot and sunny day (7 May 2019), the internal mean radiant temperature $\left(\mathrm{T}_{\mathrm{mrt}}\right)$ was higher than $\mathrm{T}_{\mathrm{a}}$. The highest temperature was $40.90^{\circ} \mathrm{C}$, recorded at 1810 , resulting from the heat transferred to the interior without sun shading (control room). The installation of the fixed sun-shading devices proved that this passive method plays a significant role in reducing $T_{\text {mrt. }}$ SDE room performed the best in reducing $\mathrm{T}_{\mathrm{mrt}}$ by $7.70 \mathrm{~K}$ compared to the control room. For SDV and SDH rooms, $\mathrm{T}_{\text {mrt }}$ were reduced by 7.10 and $6.70 \mathrm{~K}$, respectively, compared to the highest temperatures were recorded in the control room.

However, for average $\mathrm{T}_{\text {mrt }}$ within $24 \mathrm{~h}$, SDH device showed better thermal performance than the other types (Fig.
6 and Table III). The average $\mathrm{T}_{\mathrm{mrt}}$ for the control room was $33.05^{\circ} \mathrm{C}$. SDH device reduced the average $\mathrm{T}_{\text {mrt }}$ up to $1.29 \mathrm{~K}$, and SDE and SDV reduced 1.26 and $1.06 \mathrm{~K}$, respectively. Comparing the difference between SDH and SDE is only $0.03 \mathrm{~K}$. The design of SDH with fixed louvers allows for air movement and helps dissipate heat through convection. However, the design of SDE with uniform perpendicularly horizontal and vertical fixed louvers discouraged the process of night cooling.

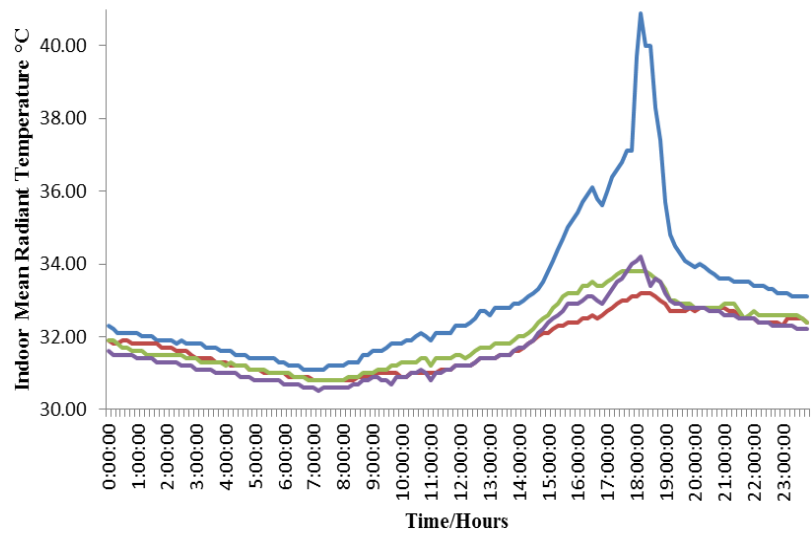

-Control -Eggcrates(SDE) - Vertical(SDV) - Horizontal(SDH)

Fig. 6: Comparison of mean radiant temperature $\left(T_{\mathrm{mrt}}\right)$ generated by each room on the sun-shading performance recorded on 7 May 2019.

Table III: Comparison of sun-shading devices performances compare to the highest $\left(T_{\mathrm{mrt}}\right)$ at control room recorded on 7 May 2019.

\begin{tabular}{|l|c|c|}
\hline $\begin{array}{c}\text { Type of Sun-Shading } \\
\text { Device }\end{array}$ & $\begin{array}{c}\text { Indoor Air } \\
\text { Temperature } \mathbf{( T}_{\text {mrt }} \text { ) }\end{array}$ & $\begin{array}{c}\text { Temperature } \\
\text { Difference }\end{array}$ \\
\hline Egg crates (SDE) & $33.20^{\circ} \mathrm{C}$ & $7.70 \mathrm{~K}$ \\
\hline Vertical (SDV) & $33.80^{\circ} \mathrm{C}$ & $7.10 \mathrm{~K}$ \\
\hline Horizontal (SDH) & $34.20^{\circ} \mathrm{C}$ & $6.70 \mathrm{~K}$ \\
\hline
\end{tabular}

From the study of one month (Fig. 7 and Table IV), the highest mean radiant temperature $\left(\mathrm{T}_{\mathrm{mrt}}\right)$ recorded was 33.32 ${ }^{\circ} \mathrm{C}$ at 1900 in the control room. The result shows that SDE performed the best by reducing $2.38 \mathrm{~K}$, followed by SDH $(2.31 \mathrm{~K})$ and SDV $(2.01 \mathrm{~K})$. The average $\mathrm{T}_{\text {mrt }}$ recorded in the control room was $31.29{ }^{\circ} \mathrm{C}$. SDE performed the best by reducing $1.11 \mathrm{~K}$ compared to SDH $(0.92 \mathrm{~K})$ and SDV (0.73 $\mathrm{K})$.

The difference of $0.19 \mathrm{~K}$ between SDE and SDH shows that both sun-shading devices are performed better at night while SDE performed at its best during daytime. These results indicate that the cooling performance happens overnight until early morning (2100-0700). A similar pattern can be noticed between the cooling effect performance of indoor air temperature and indoor mean radiant temperature. 


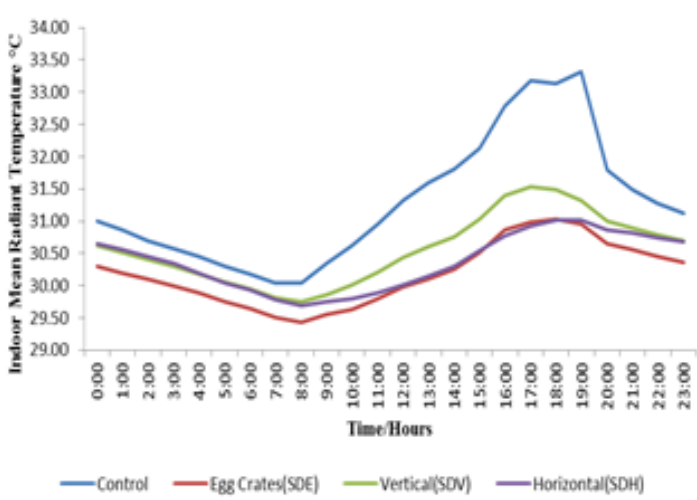

Fig. 7: Comparison of mean radiant temperature $\left(T_{m r t}\right)$ generated by each room on the sun-shading performance recorded in one month (May 2019).

Table IV: Comparison of sun-shading devices performances compare to the highest $\left(T_{\mathrm{mrt}}\right)$ at control room recorded in one month (May 2019).

\begin{tabular}{|l|c|c|}
\hline $\begin{array}{c}\text { Type of Sun-Shading } \\
\text { Device }\end{array}$ & $\begin{array}{c}\text { Indoor Air } \\
\text { Temperature ( }\end{array}$ & $\begin{array}{c}\text { Temperature } \\
\text { Difference }\end{array}$ \\
\hline Egg crates (SDE) & $30.94^{\circ} \mathrm{C}$ & $2.38 \mathrm{~K}$ \\
\hline Vertical (SDV) & $31.31^{\circ} \mathrm{C}$ & $2.01 \mathrm{~K}$ \\
\hline Horizontal (SDH) & $31.01^{\circ} \mathrm{C}$ & $2.31 \mathrm{~K}$ \\
\hline
\end{tabular}

\section{CONCLUSION}

Fixed sun-shading devices have been widely studied as one of the passive cooling systems that contributes toward indoor thermal performance. Most of the research has identified egg crate devices as the best device to improve daylight and thermal comfort. The results from this research show the importance of sun-shading devices as an effective option to regulate thermal environment. However, the performance of each type of sun-shading device depends on the design and material used. In this study, SDE performed the best in reducing the heat on the peak day and on the average result in a month. The SDE can be concluded as the best sun-shading system to reduce indoor temperature. Nevertheless, SDH showed good results in reducing mean radiant temperature at night during the hottest day. This study also indicates that SDH releases heat at night faster than other types of sun shades. This is good for thermal comfort especially when we are sleeping. SDV shows a moderate impact toward indoor thermal performance. In overall conclusion, SDE provides a better thermal performance in a room with natural ventilation.

\section{ACKNOWLEDGMENT}

The authors would like to thank and show their deepest gratitude to the Ministry of Education, Malaysia, Universiti Kebangsaan Malaysia (UKM), and Universiti Tun Hussein Onn Malaysia (UTHM) for the fund GUP-2018-096 and support during the research.

\section{REFERENCES}

1. Seyehdehzahra Mirrahimi, Mohd Farid Mohamed, Lim Chin Haw, Nik Lukman Nik Ibrahim, Wardah Fatimah Mohd Yusoff, Ardalan Aflaki, 2016. The effect of building envelope on the thermal comfort and energy saving for high-rise buildings in hot-humid climate. Renewable and Sustainable Energy Reviews 53 (2016) 1508-1519.

2. Ingy El-Darwish, Mohamed Gomaa, 2017. Retrofitting strategy for building envelopes to achieve energy efficiency. Alexandria Engineering Journal (2017) 56, 579-589.

3. Qi Jie Kwong, Yusoff Ali, 2011. A review of energy efficiency potentials in tropical buildings- perspective of enclosed common areas. Renewable and Sustainable Energy Reviews 15 (2011) 454- 4553.

4. Mohd Hafizzudin Md. Zahir, Chin Ong Woon, Sudarshan N. Raman, Mohd Farid Mohamed, Zulkifli Mohd Nopiah, 2019. A study on the perception of architects on the implementation of green roofs in Malaysia: benefits, obstacles a recommendations. Jurnal Kejuruteraan 31(2) 2019: 375-381.

5. Omidreza Saadatian, K. Sopian, C.H. Lim, Nilofar Asim, M.Y. Sulaiman, 2012. Trombe walls: A review of opportunities and challenges in research and development. Renewable and Sustainable Energy Reviews Vol. 16 (2012) 6340-6351.

6. Wardah F Mohammad Yusoff, Mohd F Mohamed, 2017. Building energy efficiency in hot and humid climate. Encyclopedia of Sustainable Technologies, Vol. 2, 159-168.

7. Wardah Fatimah Mohammad Yusoff, Elias Salleh, Nor Mariah Adam, Abdul Razak Sapian, Mohd Yusof Sulaiman, 2010. Enhancement of stack ventilation in hot and humid climate using a combination of solar collector and vertical stack. Building and Environment 45(2010) 2296-2308.

8. Wardah Fatimah Mohammad Yusoff, Abdul Razak Sapian, Elias Salleh Nor Mariah Adam, Suhana Johar, 2013. Application of solar-induced ventilation prototype in small and medium enterprise building. Indoor and Built Environment 0(0) 1-17.

9. Sabrina Barbosa, Kenneth Ip, 2014. Perspectives of double skin facades for naturally ventilated building: a review. Renewable And Sustainable Energy Reviews 40 (2014) 1019-1029.

10. Sabrina Barbosa, Kenneth Ip, Ryan Southall, 2015. Thermal comfort in naturally ventilated buildings with double skin facade under tropical climate conditions: Influence of key design parameters. Energy and Buildings 109 (2015) 397-406.

11. Francisco Fernandez Hernandez, Lopez J.M.C, Suarez J.M.P, Muriano M.C. G, Rueda S.C, 2017. Effect of louvers shading devices on visual comfort and energy demand of an office building. A Case Study. Energy Procedia 140(2017) 207-216.

12. Gianpiero Evola, Federica Gullo, Luigi Marletta, 2017. The role of shading devices to improve thermal and visual comfort in existing Glazed Buildings. Energy Procedia 134(2017) 346-355.

13. Luca Evangelisti, Claudia Guattari, Francesco Asdrubali, Roberto De Lieto Vollaro, 2020. An experimental investigation of thermal performance of a building solar shading device. Journal Of Building Engineering 28 (2020) 101089.

14. Hermawan, Eddy Prianto, Erni Setyowati, 2020. The relation between effective temperature and thermal sensation vote in tropical vernacular houses. International Journal of Engineering and Advanced Technology (IJEAT).Vol. 9 Issue 3, 2020 303-312.

15. Al-Tamimi, N.A., Fadzil, S.F.S., 2011. The potential of shading devices for temperature reduction in high-rise residential buildings in the tropics. Procedia Engineering 21(2011) 273-282.

16. Kuhn, T.E., Bühler, C., Platzer, W.J., 2001. Evaluation of overheating protection with sun shading systems. Solar Energy 69(2001) 59-74.

17. Laura Bellia, Concetta Marino, Francesco Minichiello, Alessia Pedace, 2014. An overview on solar shading systems for buildings. Energy Procedia 62 (2014) 309-317.

18. Leon Coetzee, Geoff Nitschke, 2019. Evolving optimal sun-shading building facades. GECCO '19 Companion 393-394.

19. Hua Yang, Ying Zhou, Feng-Yun Jin, Xing Zhan, 2016. Thermal environment dynamic simulation of double skin facade with middle shading device in summer. Procedia Engineering 146(2016) 251-256.

20. Mohd Khairul Azhar Mat Sulaiman, Maslina Jamil, Muhammad Fauzi Mohd Zain, 2013. Solar radiation transmission of green facade in the tropics. Kongres Penyelidikan \& Inovasi UKM 2013.

21. Frederik V. Winther, Mingzhe Liu, Per Heiselberg, Rasmus L. Jensen, 2017. Experimental and numerical analysis of modelling of solar shading. Energy Procedia 132(2017) 472-477.

22. Ауса Kirimtat, Basak Kundakci Koyunbaba, Ioannis Chatzikonstantinou, Sevil Sariyildiz, 2016. Review of simulation modelling for shading devices in buildings. Renewable and Sustainable Energy Review 53(2016) 23-49.

23. N Baker, K Steemers, Daylight Design of Buildings: A Handbook for Architects and Engineers. Routledge. 2014, pp 21-23. 
24. Salwa M. Al-Masrani, Karam M. Al-Obaidi, 2019. Dynamic shading systems: a review of design parameters, platforms and evaluation strategies. Automation in Construction 102 (2019) 195-216.

25. Salwa M. Al-Masrani, Karam M. Al-Obaidi, Nor Azizah Zalin, M.I Aida Isma, 2018. Design optimisation of solar shading systems for tropical office buildings: challenges and future trends. Solar Energy 170(2018) 849-872.

26. M.H.M. Zin, M. Jamil, N.L.N. Ibrahim, A.S M. Tazilan, 2020. Passive double skin facade (DSF) basic component and functions. International Journal of Engineering and Advanced Technology (IJEAT). Vol. 9, Issue 3, 2020, 9-15.

27. Ahmed A.Freewan, Li Shao, Saffa Riffat, 2009. Interaction between louvers and ceiling geometry for maximum day lighting performance. Renewable Energy 34(2009) 223-232.

28. A.A Freewan, L. Shao, S.Riffat, 2008. Optimizing performance of the lightshelf by modifying ceiling geometry in highly luminous climates. Solar Energy 82 (2008) 343-353.

29. Ahmed A.Y Freewan, 2014. Impact of external shading devices on thermal and daylighting performance of office in hot climate regions. Solar Energy Vol. 102 (2014) 14-30.

30. Carmen Maria Calama-Gonzalez, Rafael Suarez, Angel Luis Leon-Rodriguez, Simone Ferrari, 2019. Assessment of indoor environmental quality for retrofitting classrooms with an egg-crate shading device in a hot climate. MDPI Sustainability 2019, 111078.

31. Allen Khin Kiet Lau, Elias Salleh, Chin Haw Lim, Mohamad Yusof Sulaiman, 2016. Potential of shading devices and glazing configurations on cooling energy savings for high-rise office buildings in hor-humid climates: the case of Malaysia. International Journal of Sustainable Built Environment (2016) 5, 387-399.

\section{AUTHORS PROFILE}

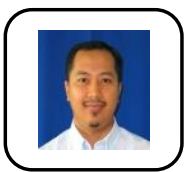

M. F. Gimat, is a Senior Architect at Department of Architecture and Planning, Development and Maintainence Office, Universiti Tun Hussein Onn Malaysia (UTHM) and a Proffesional Technologist certified by Malaysia Board of Technologist (MBOT). He obtained Bachelor of Architecture degree from Universiti Teknologi Malaysia (UTM). He is currently doing his post-graduate study at Universiti Kebangsaan Malaysia (UKM). His specialization is in building construction and project management.

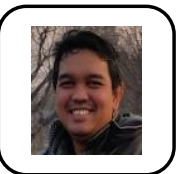

M. K. A. M. Sulaiman, is a Senior Lecturer at the Department of Architecture and Built Environment, Faculty Engineering and Built Environment in Universiti Kebangsaan Malaysia (UKM). He obtained Bachelor of Architecture degree from Universiti Teknologi Malaysia (UTM). He completed Master of Landscape Architecture from the Universiti Putra Malaysia (UPM), Serdang, Selangor, Malaysia. He graduated from the Universiti Kebangsaan Malaysia (UKM) in Doctor of Philosophy (Architecture) in 2018. His specialization is in thermal (built environment) with specific interest in vertical greenery system and shading devices. 